\title{
Pentagon keeps its fruits to itself
}

\section{Washington}

THE US Defense Department is ignoring the intent of a government programme created nine years ago to turn laboratory discoveries into commercial products by insisting that most of its awards be used to make things that the military can use.

The General Accounting Office $(\mathrm{GAO})$ reported last week that a majority of the nearly $\$ 200$ million in sales by companies funded by the Defense Department under the Small Business Innovative Research (SBIR) programme have been made to the government, not to the private sector. By contrast, companies funded by the SBIR programme within the National Institutes of Health generate 90 per cent of their revenues from commercial sales. The GAO report questions the Pentagon's "commitment to the goal of increasing private-sector commercialization".

Each federal agency that

\section{Sales of SBIR-funded companies}

percent of sales

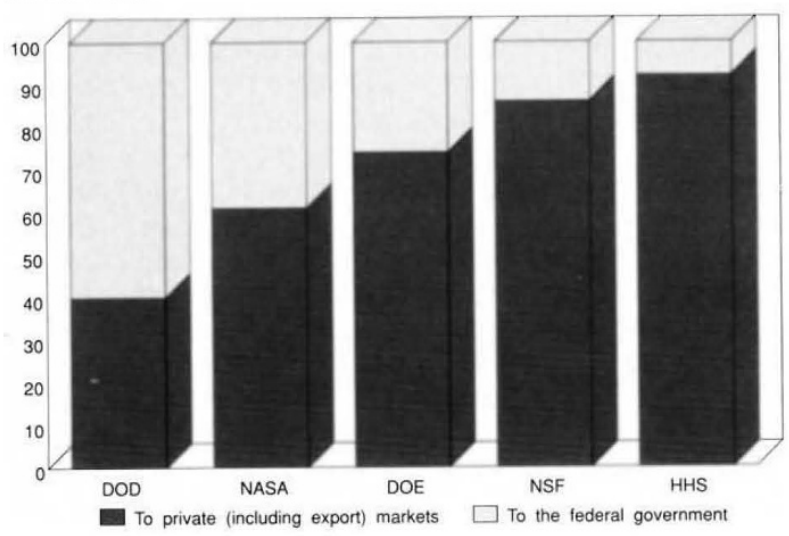

Source: General Accounting office his entrepreneurial instincts in pursuing his ideas. Those instincts, he says, have generated millions of dollars from patent licences as part of a $\$ 160$-million industry. By contrast, he says, an SBIR grant his company received from the Defense Advanced Research Projects Agency (DARPA), for drilling into crystalline rocks to great depths, was terminated after its initial phase because DARPA had learned what it needed to know.

A Pentagon official defended the military's emphasis on 'mission-oriented' research. Ray Wrenn, who runs the SBIR programme for the Defense Department, said that comparisons between his agency and basic research agencies such as NSF and $\mathrm{NIH}$ are "inappropriate and misleading". Wrenn also said that many of the Pentagon's SBIR grants go to "leading-edge technology where the commercial market has yet to be established".

Keith Fultz, who directed the approach to SBIR during testimony last week to the technology subcommittee of the Science, Space and Technology Committee of the US House of Representatives, which requested the GAO report. The subcommittee is considering whether to renew the programme, which expires in 1993.

Browning says that his company was founded on SBIR grants from NSF, which gave him almost total freedom to follow
GAO study, told the congressional panel that one way to promote commercial sales is to encourage the Pentagon to support technologies that can be used by both the military and the civilian sector. He pointed to several examples where SBIR projects funded by the Pentagon generated sales to both sectors. But he appeared sceptical that the department would loosen its strict rules about the applicability of projects to military needs.

Jeffrey Mervis

\section{The rising price of helping Bulgarian science}

\section{Tokyo}

A JAPANESE researcher, with the help of Japan's usually stodgy bureaucracy, has kept alive for a year a whole laboratory of Bulgarian scientists and technicians. But his creative use of a mere US $\$ 50,000$ from his large government grant may be foiled by the rising price of freedom in Eastern Europe.

Kuniaki Nagayama, a researcher at JEOL Ltd., a manufacturer of advanced microscopes, received an 'SOS' in December 1990 from Ivan Ivanov, head of the Laboratory of Thermodynamics and Physico-chemical Hydrodynamics at the University of Sophia in Bulgaria. Ivanov wrote that his team of researchers was on the verge of breaking up because of a lack of funds and a brain drain following the political upheavals in Eastern Europe.

Nagayama decided that Ivanov's team could make a significant contrbution to his 'Protein Array' project funded by the Exploratory Research for Advanced Tech- nology (ERATO) programme of the Research and Development Corporation of Japan (JRDC).

With the help of JRDC officials, Nagayama bent the rules governing ERATO projects to provide Ivanov's team with a small but significant sum of money. The \$50,000 was channelled to Ivanov's laboratory under a system normally used for contracting out data analysis to private companies or other research organizations. It has been enough to hold together Ivanov's team of 18 scientists and technicians for the past year. In addition, two researchers from Ivanov's team have spent a year in Japan under the ERATO grant.

The system of support set up by Nagayama has turned out to be a costeffective way of carrying out research that, at the same time, supports science in Eastern Europe. Genya Chiba, vice president of JRDC, says that it costs almost as much to bring one Bulgarian scientist to
Japan for a year as to support the whole of Ivanov's laboratory in Sophia University for the past year. But it is becoming more expensive by the day.

Bulgaria suffered a sharp rise in prices last year following moves towards a more free-market economy. Ivanov wants almost twice as much money next year so that he can pay higher salaries to his team. Although plenty of money exists within Nagayama's ERATO grant to cover the request, it would be an unprecedented amount of money for outside, contracted research. A decision is expected soon.

In the long run, Nagayama hopes that the laws governing the ERATO programme will be changed to make it easier to provide ERATO funds to research teams overseas. And he hopes his small initiative will serve as a model for Western nations and Japan to help maintain the research infrastructure in Eastern European countries and the former Soviet Union.

David Swinbanks 